\title{
Micronutrients limiting pasture production in Australia
}

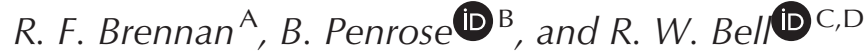 \\ AFormerly: Department of Primary Industries and Regional Development, Albany Regional Office, 444 Albany \\ Highway, Albany, WA 6330, Australia. \\ ${ }^{B}$ Tasmanian Institute of Agriculture, University of Tasmania, Private Bag 98, Hobart, Tas. 7001, Australia. \\ ${ }^{\mathrm{C}}$ Agriculture Discipline, College of Science, Health, Engineering and Education, Murdoch University, \\ Murdoch, WA 6150, Australia. \\ ${ }^{D}$ Corresponding author. Email: R.Bell@murdoch.edu.au
}

\begin{abstract}
Low levels of plant-available micronutrients were an inherent feature of many agricultural soils in Australia, mostly due to the prevalence of highly weathered soil parent materials. The diagnosis and correction of the widespread deficiencies of micronutrients, especially copper $(\mathrm{Cu})$, molybdenum $(\mathrm{Mo})$ and zinc $(\mathrm{Zn})$, were prerequisites for the development of productive, legume-based pastures in southern Australia. In subtropical and tropical regions, Mo deficiency commonly limited pasture-legume production. Soil treatments involving micronutrient fertiliser incorporated in soils, or applied as additives to superphosphate, were generally effective in alleviating micronutrient deficiencies. In the low-output dryland pasture systems, the annual removal of micronutrients in wool and meat is small compared with rates added in fertiliser. Hence, in general, the residues of soil-applied micronutrient fertilisers remain effective for many years, for example, up to 30 years for $\mathrm{Cu}$. By contrast, shorter residual values occur for manganese (Mn) fertiliser on highly calcareous soils, and for $\mathrm{Zn}$ in high-output pasture systems such as intensive dairy production. In the last two decades since the recommendations for micronutrient management of pastures were developed, there have been many changes to farming systems, with likely implications for micronutrient status in pastures. First, increased cropping intensity and low prices for wool and meat have meant lower nutrient inputs to pastures or to the pasture phase of rotations with crops. However, when pastures have been rotated with crops, ongoing small additions of $\mathrm{Cu}, \mathrm{Zn}$ and $\mathrm{Mo}$ have been common. In cropping phases of farming systems, lime application and no-till may have altered the chemical and positional availability of micronutrients in soils to pastures. However, there has been little study of the impacts of these farming-systems changes on micronutrient status of pastures or profitability of the production system. The intensification of dairy production systems may also have altered the demand for, and removal rates of, micronutrients. Soil tests are not very reliable for Mn or Mo deficiencies, and well-calibrated soil tests for boron, $\mathrm{Cu}$ and $\mathrm{Zn}$ have been developed only for limited areas of pasture production and for a limited range of species. There is limited use of plant tests for nutrient management of pastures. In conclusion, there is limited knowledge of the current micronutrient status of pastures and their effects on animal health. Pasture production would benefit from targeted investigation of micronutrients status of pasture soils, pasture plants and micronutrient-linked animal-health issues.
\end{abstract}

Additional keywords: nitrogen fixation, residual value, subterranean clover pasture.

Received 28 February 2019, accepted 1 November 2019, published online dd mmm yуyy

\section{Introduction}

The micronutrient elements known to be essential for both grass and legume pasture plants are boron $(\mathrm{B})$, chlorine $(\mathrm{Cl})$, copper $(\mathrm{Cu})$, iron $(\mathrm{Fe})$, manganese $(\mathrm{Mn})$, molybdenum $(\mathrm{Mo})$, nickel (Ni) 5 and zinc $(\mathrm{Zn})$ (Bell and Dell 2008). Legumes that depend on dinitrogen $\left(\mathrm{N}_{2}\right)$ fixation for their $\mathrm{N}$ supply require Mo in greater amounts for symbiotic function than for the growth of the host plant, and they also require cobalt $(\mathrm{Co})$ as a nutrient for the rhizobia. In addition, sodium $(\mathrm{Na})$, selenium (Se) and silicon ( $\mathrm{Si}$ ) have been shown to be beneficial to plants in some cases, without satisfying the criteria for essentiality for all plants (Marschner 2011). All of the elements essential for plants, with the exception of B, are essential for animals (Bell and Dell 2008). In addition, animals require iodine (I), Se and chromium $(\mathrm{Cr})$ (Underwood and Suttle 1999). Under rigorously controlled laboratory conditions, fluorine (F) and $\mathrm{Si}$ have also been shown to be beneficial, particularly when added in minute amounts to purified diets for animals (Underwood and Mertz 1987; Underwood and Suttle 1999). However, there is no evidence of $\mathrm{Cr}, \mathrm{Ni}, \mathrm{F}$ or Si being deficient in pasture ecosystems, and they are not considered further in this paper.

In Australia, most micronutrients are supplied to animals from the direct consumption of pasture or forage species by the grazing animal. Both grass and legume plant species require micronutrients to be taken up from soil solution for adequate, normal or maximum growth. However, agricultural soils vary 
widely in total content and plant-available forms of micronutrients and plant species may vary in their requirements (White and Zasoski 1999). Sillanpää (1982) reported micronutrient deficiency in plants from almost every 5 country in their study.

A generalised map of the areas of agricultural soils with inherent micronutrient deficiency risk is presented in Fig. 1. In south-west Western Australia (WA), 8-9 Mha of land was inherently deficient in $\mathrm{Cu}, \mathrm{Zn}$ and $\mathrm{Mo}$, and to a lesser extent $\mathrm{Mn}$.

10 Molybdenum deficiency was widespread in pasture legumes in subtropical and tropical pastures of Australia, particularly on acid basaltic soils. In southern Australia, the areas at risk correspond well with the extent of improved pastures.

A feature of agricultural production in southern Australian until the 1980s was the crop-pasture (ley farming) system in which the main pasture species was subterranean clover (Trifolium subterraneum L), which supplied the $\mathrm{N}$ required for crop production and suppressed crop diseases, especially those of wheat (Triticum aestivum L.) (Doole and Weetman 2009). On alkaline soils, particularly in South Australia (SA), medics (Medicago spp.) were commonly used instead of 10 subterranean clover in the pasture ley in rotations with wheat

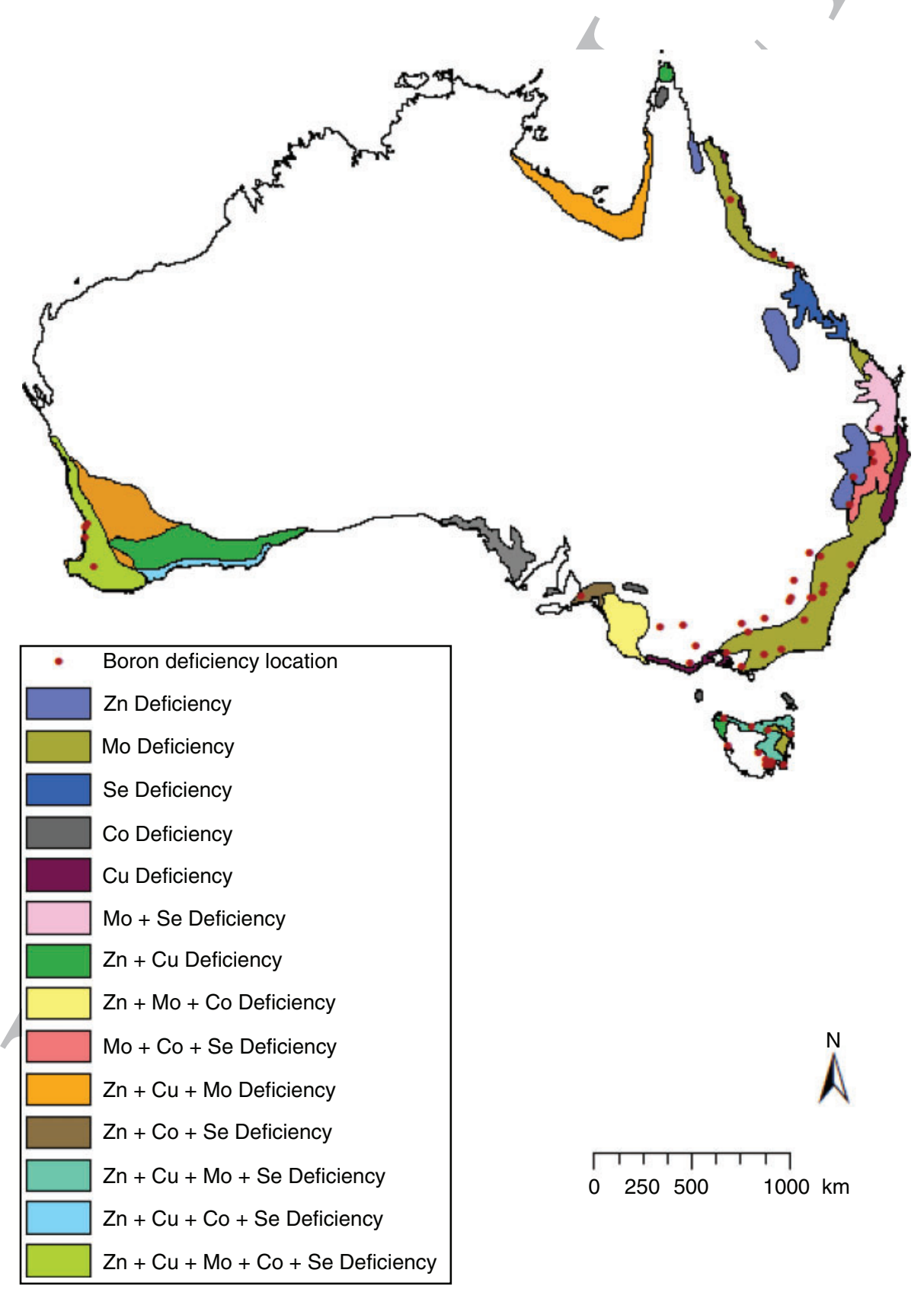

Fig. 1. Inherent and potential micronutrient deficiencies in agricultural soils. Modifed from Hayes et al. (2019). 
and barley (Hordeum vulgare L.). A history of pastures in the ley farming system and their importance to agricultural production systems in southern Australia is outlined by Fitzpatrick (2011).

Since the 1980s, land use has changed towards more extended 5 periods of cropping or continuous cropping. No-tillage planting of crops has become more prevalent, especially in WA and SA, where it covers $90 \%$ of the cropping area (Rochecouste and Crabtree 2014). In addition, low prices for wool and meat have led to to decreased inputs, including fertiliser, in the pasture 10 phase. Soil acidification has continued because of inadequate use of lime. Even where programs of lime application have raised topsoil $\mathrm{pH}$, subsoil acidification often continues (Gazey et al. 2014). A greater diversity of pasture legume and grass species has also been introduced, including more herbaceous and 15 woody perennial species (e.g. Moore et al. 2006). Hence, there have been several changes in farming systems that have consequences for micronutrient supply and availability to pastures and grazing animals. Although micronutrient management packages for southern Australian (WA and SA)

20 farming systems have been developed, these were mainly for cropping and mostly designed for farming systems $>40$ years ago. These packages may not be adequate for contemporary pasture systems. The recommendations for micronutrients may also be inadequate for more intensive grazing systems such as strip-grazing in dairy livestock systems.

According to Judson and McFarlane (1998), the main trace element deficiencies for grazing livestock are $\mathrm{Co}, \mathrm{Cu}, \mathrm{I}, \mathrm{Mn}, \mathrm{Se}$ and $\mathrm{Zn}$. Mild mineral deficiencies are especially difficult to identify because their effects are rarely distinguishable from

30 those due to underfeeding or intestinal parasitism. An initial assessment of the actual or likely occurrence of a dietary mineral inadequacy can be made by comparing the mineral composition of the diet with recommended levels (Underwood and Suttle 1999). These factors are frequently not integrated into fertiliser

35 decision support systems for recommending micronutrients in the pasture-crop system.

\section{Essential elements for pasture and animal production}

Pastures plants in Australia generally come from the grass (Poaceae) and legume (Fabaceae) families. The function and

40 importance of the essential micronutrients for plants, rhizobia and ruminants have been well reviewed (e.g. Minson 1990; Blevins and Lukaszewski 1998; Gerendás et al. 1999; Underwood and Suttle 1999; O'Hara 2001; White and Broadley 2001; Brown et al. 2002; Hänsch and Mendel 2009;

45 González-Guerrero et al. 2014). Here we provide a brief overview of the function of these elements for plants, rhizobia and ruminants, and have indicated sources where more detailed accounts can be found.

\section{Boron}

50 Boron is required in plants for cell wall structure through its association with pectin, as well as having roles in membrane structure and function, detoxifying reactive oxygen species (ROS), and phenol metabolism (Blevins and Lukaszewski 1998; Brown et al. 2002).

55 In the legume-rhizobia symbiosis, B is fundamental to nodgene activation by root exudates and is required for nodule initiation, infection thread development and nodule invasion (Bolaños et al. 1996; Redondo-Nieto et al. 2001).

\section{Chlorine}

Chlorine is important to plants for osmotic regulation and turgor in the vacuole, reactivity of enzymes, regulation of intercellular $\mathrm{pH}$ gradients, membrane potential, and photosynthesis (Welch and Shuman 1995; White and Broadley 2001).

Cobalt

In rhizobia, Co forms the coenzyme cobalamin (vitamin B12), which is used for methionine synthesis, the synthesis of DNA precursors and the synthesis of leghemoglobin, which provides the oxygen required for the reduction of $\mathrm{N}_{2}$ to ammonia $\left(\mathrm{NH}_{3}\right)$ during $\mathrm{N}$ fixation (Drennan et al. 1994; Becana et al. 2000; O'Hara 2001).

Rumen microorganisms, similar to rhizobia, require Co for the synthesis of vitamin B12. Cobalt deficiency leads to a reduction in methylation, abnormal lipid metabolism, decreased blood haemoglobin and protein, urea and cholesterol in the serum, and impaired disease resistance (Minson 1990; Spears 1999; Underwood and Suttle 1999).

Copper

In plants, Cuplays important roles in photosynthesis and electron transport, as an enzyme co-factor, in cell-wall metabolism and oxidative stress response, and in abiotic stress signalling (Yruela 2009).

In rhizobia, $\mathrm{Cu}$ is required for $\mathrm{N}$ fixation, is needed for rhizobial respiration, and is involved in detoxification of ROS produced in the N-fixation process (Preisig et al. 1996; GonzálezGuerrero et al. 2014).

In ruminants, $\mathrm{Cu}$ is a component of many important enzymes including lysyl oxidase, ceruloplasmin, tyrosinase, cytochrome oxidase and superoxide dismutase, and is required for reproduction, bone development, and growth and development of connective tissue (Spears 1999). Insufficient $\mathrm{Cu}$ intake can lead to anaemia, bone disorders, connective-tissue disorders, neonatal ataxia or 'swayback' in lambs born to $\mathrm{Cu}$-deficient ewes, cardiovascular disorders, diarrhoea, infertility and increased susceptibility to infection (Underwood and Suttle 1999). Copper deficiency also causes 'steely wool', where the wool is weakened and the fibre is straight and lustrous and loses its characteristic crimp (Lee 1956); it can cause the fleeces of black sheep to lose their pigmentation (Smith and Gawthorne 1975).

\section{lodine}

Iodine is crucial in ruminants for the function of the thyroid hormones, thyroxine and triiodothyronine, which control oxidation rates and protein synthesis in cells (Spears 1999; Underwood and Suttle 1999). These hormones are important for fetal development, lipid, carbohydrate and $\mathrm{N}$ metabolism, regulation of energy metabolism, digestion, growth, muscle function, reproductive performance, and immune defence (Minson 1990; Underwood and Suttle 1999). Iodine deficiency can result in an enlargement of the thyroid gland in the neck (goitre). Iodine deficiency can lead to impaired brain 
development, impact on reproductive success, growth and postnatal mortality, and result in low milk yield (Underwood and Suttle 1999).

Iron

5 In plants, $\mathrm{Fe}$ is involved in photosynthesis, $\mathrm{N}$ assimilation, synthesis of hormones, regulation of ROS, osmoprotection, and mitochondrial respiration (Hänsch and Mendel 2009).

Many proteins involved in the legume-rhizobia symbiosis contain Fe. These include nitrogenase, which is integral to $\mathrm{N}$

10 fixation; ferredoxin, which is involved in electron transfer and reducing the $\mathrm{Fe}$ component of nitrogenase; and leghemoglobin, which helps to control oxygen concentrations for $\mathrm{N}$ fixation and respiration (Brear et al. 2013).

In ruminants, $\mathrm{Fe}$ is an important constituent of haemoglobin 15 and myoglobin, which are vital to oxygen transport in the blood. Iron is also involved in electron transport and is a component of many enzymes (Spears 1999; Underwood and Suttle 1999). Its deficiency in ruminants leads to anaemia, which can cause a loss of appetite, reduced growth, lethargy, lightening of mucous 20 membranes, increased respiration rate, and death in severe cases (Underwood and Suttle 1999).

\section{Manganese}

Manganese plays important roles in plants by catalysing reactions and activating enzymes (Hänsch and Mendel 2009).

25 Examples of its functions in plants include the water-splitting system of photosystem II, synthesis of ATP, ribulose-1,5bisphosphate carboxylase reactions, and biosynthesis of chlorophyll, fatty acids, lipids, aromatic amino acids, lignins, flavonoids and phytohormones, and it is involved in defence

30 against ROS (Campbell and Nable 1988; Hänsch and Mendel 2009; Millaleo et al. 2010). In rhizobia, Mn is required for enzyme function and in nodulation and N fixation (O'Hara 2001).

Manganese is a key component of several important enzymes in ruminants, including pyruvate carboxylase, arginase 35 and mitochondrial superoxide dismutase (Spears 1999; Underwood and Suttle 1999). It has functions in cartilage and bone development, synthesis of prothrombin (involved in blood clotting), lipid and carbohydrate metabolism, and protecting cells from damage due to ROS (Minson 1990; Underwood and Suttle

40 1999). Manganese deficiency can cause skeletal abnormalities, reproductive disorders and disproportionate loss of female fetuses (Minson 1990; Underwood and Suttle 1999).

\section{Molybdenum}

Molybdenum is a key component of four important plant 45 enzymes: nitrate reductase, which reduces nitrate to nitrite; peroxisomal sulfite oxidase, which detoxifies excess sulfite; aldehyde oxidase, which is integral to the biosynthesis of abscisic acid; and xanthine dehydrogenase, which is important in purine catabolism, response to pathogens and other stressors,

50 and senescence (Schwarz and Mendel 2006). In rhizobia, Mo is required as it is a key component of nitrogenase, which enables $\mathrm{N}$ fixation (O'Hara 2001).

In ruminants, Mo is a component of the enzymes xanthine oxidase, sulfite oxidase and aldehyde oxidase (Spears 1999).

55 High Mo concentrations reduce the availability of $\mathrm{Cu}$, and this apparent $\mathrm{Cu}$ 'deficiency' due to high Mo is often exacerbated by low $\mathrm{Cu}$ status in the animal (Underwood and Suttle 1999; Whitehead 2000).

Nickel

Nickel is important for urease activity and ureide metabolism, as well as seed viability (Welch and Shuman 1995; Hänsch and Mendel 2009). In rhizobia, $\mathrm{Ni}$ is required for efficient $\mathrm{N}$ fixation because it is needed by hydrogenase, which recycles the $\mathrm{H}_{2}$ produced by nitrogenase (Gerendás et al. 1999).

\section{Selenium}

Selenium is required by rhizobia because it is a crucial component of several seleno-amino acids including selenocysteine, which is present in several important enzymes, and selenomethionine, which is an antioxidant important for detoxifying ROS (Ekanayake et al. 2017).

In ruminants, $\mathrm{Se}$ is a component of some enzymes and selenoproteins including glutathione peroxidase and iodothyronine deiodinases, and works with vitamin $\mathrm{E}$ to detoxify ROS (Spears 1999; Underwood and Suttle 1999). Selenium is required for growth, reproduction and protection from disease (Underwood and Suttle 1999). Selenium deficiency can cause reductions in growth rate, milk production and fat percentage, wool production and fertility (Minson 1990).

\section{Zinc}

Zinc is a cofactor of many plant enzymes (Brown et al. 1993) including zinc finger proteins, which bind DNA, RNA, proteins and other molecules, regulate stomatal closure and provide protection from ROS (Broadley et al. 2007).

In rhizobia, $\mathrm{Zn}$ is involved in carbonic anhydrase, which is important for root nodulation (Vance 2008). Zinc is also required for $\mathrm{N}$ fixation in the nodule, although its role(s) in $\mathrm{N}$ fixation are not fully elucidated (León-Mediavilla et al. 2018).

Zinc is a constituent in many ruminant enzymes including DNA and RNA polymerases, alcohol dehydrogenase and pyruvate dehydrogenase. It is important in vitamin A metabolism, is involved in gene expression and membrane stability, and regulates appetite (Spears 1999; Underwood and Suttle 1999). Zinc deficiency can reduce growth, fertility and milk production, cause a loss of appetite and skeletal disorders, and impair testicular development (Minson 1990; Underwood and Suttle 1999). Zinc deficiency can also cause wool to become brittle and thin and to lose its crimp (Mills et al. 1967; Underwood and Somers 1969).

\section{Soil factors affecting micronutrient availability}

Pasture plants and their associated symbiotic microorganisms obtain most of their micronutrients via the soil (see example of $\mathrm{Zn}$ in Fig. 2). However, the availability of these micronutrients for uptake is significantly affected by several soil factors including concentration of the element, soil type, clay percentage and clay type, organic matter concentration, soil $\mathrm{pH}$ and soil moisture (Whitehead 2000; Bell and Dell 2008).

In general, the availability of the micronutrients occurring as cations, especially $\mathrm{Fe}, \mathrm{Mn}, \mathrm{Zn}$ and $\mathrm{Co}$, tends to increase with declining soil $\mathrm{pH}$, whereas the availability of the micronutrients 


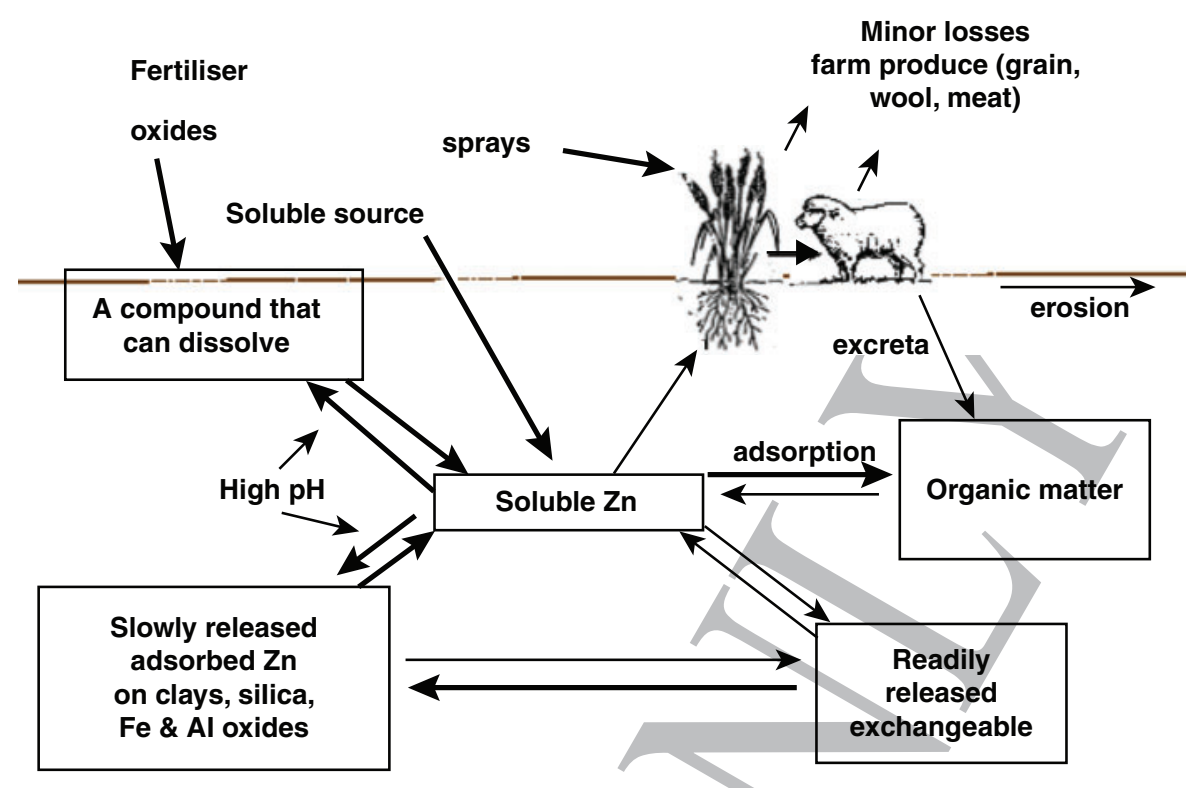

Fig. 2. The soil-plant-animal cycle, using zinc $(\mathrm{Zn})$ as an example, with possible $\mathrm{Zn}$ additions and losses to this system for soils of Western Australia (Brennan 2005). Note that the leaching process is non-existent for zinc.

occurring as anions (B, Mo and Se) tends to decrease with declining soil $\mathrm{pH}$. The effects of lime on concentrations of micronutrient elements in pasture herbage are due partly to the addition of $\mathrm{Ca}$ and partly to the increase in soil $\mathrm{pH}$. When 5 liming results in an appreciable increase in soil $\mathrm{pH}$ (e.g. from $\mathrm{pH}$ $<5.5$ to $\geq 7.0$ ), there is usually a substantial reduction in the concentrations of $\mathrm{Fe}, \mathrm{Mn}$ and $\mathrm{Co}$, a small reduction or little difference in $\mathrm{Zn}$ and $\mathrm{Cu}$, and an increase in Mo (Mitchell 1963; Stewart and McConaghy 1963; Price and Moschler 1965, 1970;

Soil $\mathrm{pH}$ in particular has a large effect on the availability of micronutrients for plant uptake, with $\mathrm{B}, \mathrm{Co}, \mathrm{Cu}$ and $\mathrm{Mn}$ being most available at $\mathrm{pH}$ in the range 5.0-7.0 (Bell and Dell 2008), and Mo at pH 5.0-6.0 (Sillanpää 1982). Victoria, Tasmania, 15 coastal New South Wales and Queensland, and south-west WA have generally acidic topsoils ( $\mathrm{pH}$ 4-5.5) (de Caritat et al. 2011), which can make micronutrients such as Mo relatively unavailable for pasture uptake (Fig. 1). These areas also happen to include important areas for improved pastures

20 supporting dairying (Dairy Australia 2018), beef production (MLA 2018a) and sheep production (MLA 2018b); therefore, the low $\mathrm{pH}$ in these regions may significantly affect Australian pasture and animal production as a whole, in part through effects on micronutrient availability.

25 Species and varietal differences in micronutrient concentrations

There can be considerable differences in micronutrient concentrations among species of grasses and legumes (Whitehead 2000). Legumes often contain higher

30 concentrations of $\mathrm{Fe}, \mathrm{Zn}, \mathrm{Cu}$ and $\mathrm{Co}$ than grasses, whereas $\mathrm{Mn}$ concentrations are sometimes higher in grasses than in legumes (O'Hara 2001). However, whether legumes or grasses have higher concentrations also depends on the soil concentration of the element (i.e. high or low; Whitehead 2000).

Differences in shoot micronutrient concentrations also exist among cultivars or varieties of the same species. Significant differences in micronutrient concentrations have been found among cultivars of prairie grass (Bromus willdenowii Kunth) for $\mathrm{Fe}, \mathrm{Mn}, \mathrm{Zn}$ and $\mathrm{Cu}$ (Rumball et al. 1972); Rhodes grass (Chloris gayana Kunth) for B, Mn and Zn (Jones et al. 1995); and red clover (Trifolium pratense L.) for Fe and $\mathrm{Zn}$ (Lindström et al . 2013). Differences in micronutrient concentrations were also found in cocksfoot (Dactylis glomerata $\mathrm{L}$.) for $\mathrm{Co}, \mathrm{Cu}, \mathrm{Mn}$ and $\mathrm{Zn}$ (Forbes and Gelman 1981) and in perennial ryegrass (Lolium perenne L.) for $\mathrm{B}, \mathrm{Co}, \mathrm{Cu}, \mathrm{Fe}, \mathrm{Mn}, \mathrm{Mo}$, Se and $\mathrm{Zn}$ (Crush et al. 2018). However, inter-varietal differences in micronutrient concentrations were not always consistent among sampling times or sites. More data are needed to establish whether it is feasible to breed varieties of pasture grasses or legumes with consistently higher shoot micronutrient concentrations.

\section{Residual value of micronutrient fertiliser additions}

A distinctive feature of micronutrient management for pastures is the long residual value of micronutrient additions to soils relative to that of macronutrient fertilisers. Hence, after diagnosis of deficiency and determination of the optimum rate to correct deficiency in pastures, the next key step in fertiliser decision making is to estimate the residual value of the applied fertiliser. The residual value refers to how long after the initial application an adequate supply of nutrient to the pasture plant is maintained for maximum pasture and animal production. Knowledge of the residual value of micronutrient fertiliser is therefore important for determining when a further application of the micronutrient is required to prevent deficiency re-occurring and reducing pasture herbage yield or animal production (including wool and milk output). To estimate the residual value of a micronutrient 
fertiliser, it is necessary to know which soil properties control chemical reactions, losses and additions in the soil-plant cycle because these determine the availability of the nutrient within the soil for pasture plants (Fig. 2).

5 Reactions of applied micronutrients with the soil constituents are the major cause of reduction in nutrient availability with time. Losses by leaching appear negligible even in sandy soils for most micronutrients (e.g. Cu, Gartrell 1981; Zn, Brennan and McGrath 1988). Boron, by contrast, is leachable on sands (Bell 1999). The

10 amounts of micronutrients removed in harvested products from pastures (hay, wool, body mass) vary markedly for each element but generally are low or minute compared with the amounts added in fertiliser (Table 1). The typical removal of $\mathrm{Zn}$ for wool and meat $\left(<10 \mathrm{~g} \mathrm{Zn} \mathrm{ha}^{-1}\right)$ is $60-80 \%$ less than for dairy cattle 5 production for milk (27-46 $\left.\mathrm{g} \mathrm{ha}^{-1} \mathrm{year}^{-1}\right)$. However, in dairy production systems, cattle are fed grain and other supplements bought onto the farm. Further studies are needed to determine the micronutrient balance in typical dairy systems, after accounting for all input and outputs.

20 Based on the rates of $\mathrm{Zn}$ fertiliser applied to soils of WA for cereal and pasture production, $\mathrm{Zn}$ is predicted to have a long residual value (Brennan and Bolland 2007). Even if 70\% of an initial $\mathrm{Zn}$ application is strongly sorbed by the soil, based on the small rates of $\mathrm{Zn}$ removal, the residual $\mathrm{Zn}$ is likely to supply

25 crop and pasture requirements for 17 years (Brennan 2005). According to Brennan and Bolland (2007), $1 \mathrm{~kg} \mathrm{Zn} \mathrm{ha}^{-1}$ added as fertiliser would remain effective for 40 years of supply on a yellow duplex soil. In another study, after 17 years, the $1 \mathrm{~kg} \mathrm{Zn}$ $\mathrm{ha}^{-1}$ remained fully effective in correcting $\mathrm{Zn}$ deficiency in six

30 grain crops (Brennan and Bolland 2006); however, like much of this work, the study did not include pasture species, and data are still limited to a small range of soil types. Micronutrients may also be supplied in NPK fertilisers, as either intentional or incidental constituents. Some fertilisers contain appreciable 35 amounts of micronutrients, especially those derived from phosphate rock. For example, Verloo and Willaert (1990) reported $\mathrm{Zn}$ concentrations varying from $6 \mathrm{mg} \mathrm{kg}^{-1}$ in potassium chloride and $12 \mathrm{mg} \mathrm{kg}^{-1}$ in ammonium nitrate to $244 \mathrm{mg} \mathrm{kg}^{-1}$ in superphosphate. Similarly, research with cereal 40 crops in WA has shown that regular (usually annual) application of $>150 \mathrm{~kg}$ superphosphate ha ${ }^{-1}$ incidentally containing 400-600 $\mathrm{mg} \mathrm{Zn} \mathrm{kg}{ }^{-1}$ supplied sufficient amounts of $\mathrm{Zn}$ to meet the requirements of the current crop and pasture production indefinitely (Brennan 2005). Frequently, these additions of

Table 1. Typical amounts removed of copper $(\mathrm{Cu})$, molybdenum (Mo) and zinc ( $\mathrm{Zn})$ in wheat or barley grain, lupin seed, wool, meat or milk

\begin{tabular}{lccc}
\hline Product & $\mathrm{Cu}$ & Mo & $\mathrm{Zn}$ \\
\hline Wheat or barley grain $\left(\mathrm{g} \mathrm{t}^{-1}\right)$ & $8^{\mathrm{A}}, 3^{\mathrm{B}}$ & $0.16-0.2^{\mathrm{C}}$ & $5-25^{\mathrm{B}, \mathrm{D}}$ \\
Lupin seed $\left(\mathrm{g} \mathrm{t}^{-1}\right)$ & $5^{\mathrm{E}}, 4^{\mathrm{B}}$ & $1.8^{\mathrm{E}}$ & $17-30^{\mathrm{B}, \mathrm{D}}$ \\
Sheep for wool production $\left(\mathrm{g} \mathrm{ha}^{-1}\right)$ & $0.3^{\mathrm{A}}$ & $<10^{\mathrm{D}}$ \\
Sheep for meat production $\left(\mathrm{g} \mathrm{ha}^{-1}\right)$ & $>12^{\mathrm{A}}$ & $<10^{\mathrm{D}}$ \\
Dairy cattle for milk production $\left(\mathrm{g} \mathrm{ha}^{-1}\right)$ & & & $27-46^{\mathrm{F}}$ \\
\hline
\end{tabular}

${ }^{\mathrm{A}}$ Gartrell (1981). ${ }^{\mathrm{B}}$ White et al. (1981). ${ }^{\mathrm{C}}$ Gupta (1971). ${ }^{\mathrm{D}}$ Brennan (2005).

${ }^{\mathrm{E}}$ White et al. (2007). ${ }^{\mathrm{F}}$ Dr M Staines, DPIRD, Busselton, WA, provided milk production data used for the calculation, which accounts only for removal in milk, not for removal in bodyweight of animals removed; $\mathrm{Zn}$ concentrations in milk taken from Dunshea et al. (2019). superphosphate have maintained adequate $\mathrm{Zn}$ levels in soils despite any decline in the effectiveness of the original $\mathrm{Zn}$ application as Zn fertiliser (Brennan 1998, 2000).

Micronutrient additions through applications of macronutrient fertiliser to agricultural soils are a major source of micronutrient supply for pasture plant growth (Naidu et al. 1996). It is unusual for the amount of micronutrients added in macro or compound fertiliser to be taken up and completely removed; hence, the remainder adds to the soil reserves of micronutrients. Also, a proportion of the fertiliser nutrient that is taken up is subsequently returned to the soil in plant residues or manures and urine of grazing animals, and hence adds to the micronutrient soil reserves. Other inputs from straw, hay, silage, sewage waste and animal manure are generally less important sources of micronutrients for pasture systems in Australian agriculture (Fig. 2). Similarly, industrial and manufacturing processes and the disposal of domestic and industrial wastes that contribute to micronutrient enrichment of soils are not currently of major importance for Australian agriculture. Increased recycling of urban composts or sewerage sludge and their derivative products would increase the recycling of $\mathrm{Zn}, \mathrm{Cu}$ and $\mathrm{Ni}$, in particular, onto agricultural land. In this situation, a risk assessment based on the increased load of micronutrients and soil reactivity would be needed.

Case study of the residual value of $\mathrm{Zn}$ for pasture

Zinc cycling in the soil-plant-animal system is a process not well documented in the literature. The $\mathrm{Zn}$ in herbage harvested as pasture hay is either returned to the soil via animal excreta or removed if the produce is exported off the farm (meat, wool, and milk). For example, pasture hay yielding $7 \mathrm{t} \mathrm{ha}^{-1}$ would remove $\sim 175 \mathrm{~g} \mathrm{Zn} \mathrm{ha}^{-1}$ if taken away from the farm, as calculated from pasture Zn levels in WA from Masters and Somers (1980). The amounts removed in the produce of animals are typically low relative to the amount of fertiliser $\mathrm{Zn}$ applied. In animals, the whole body concentration of $\mathrm{Zn}$ on a fresh basis ranges from 20 to $30 \mathrm{mg} \mathrm{kg}^{-1}$ in cows (Miller et al. 1974) and sheep (Grace 1983), or on a dry-weight basis from 20 to $250 \mathrm{mg} \mathrm{kg}^{-1}$ (Underwood 1977; O'Dell 1979; Hill et al. $1983 a$, 1983b, 1983c). However, in the case of sheep, $\sim 55 \%$ of the body's Zn can be in wool. Masters and Moir (1980) found $\sim 110 \mathrm{mg} \mathrm{Zn} \mathrm{kg}^{-1}$ in the wool of sheep from WA. Typical wool production is $60-80 \mathrm{~kg} \mathrm{ha}^{-1}$ during spring (August-November) in intensively grazed pasture systems of WA (Thompson et al. 1994, 1997; Hyder et al. 2002). Hence, annual $\mathrm{Zn}$ removal in wool ranges from $\sim 6.5$ to $8.8 \mathrm{~g} \mathrm{ha}^{-1}$. Similarly, 50-kg mature Merino wethers grazed at 12 sheep ha ${ }^{-1}$ (Thompson et al. 1997) and containing $30 \mathrm{mg}$ $\mathrm{Zn} \mathrm{kg}^{-1}$ body mass (Grace 1983) would remove $\sim 1.8 \mathrm{~g} \mathrm{Zn} \mathrm{ha}^{-1}$ from a grazed pasture system in WA. The annual loss of $\mathrm{Zn}$ from an intensively grazed system, assuming complete removal of the animals and wool ( 8-10 $\left.\mathrm{g} \mathrm{Zn} \mathrm{ha}^{-1}\right)$ from the system, represents $\sim 1-1.5 \%$ of the amount of $\mathrm{Zn}$ typically applied initially as a fertiliser in agricultural systems of WA. In set-stocking-rate grazing systems (Thompson et al. 1994, 1997; Hyder et al. 2002), the loss of $\mathrm{Zn}$ from the system would be about onethird to one-half that calculated for the intensively grazed system. The set-stocking-rate grazing system is the more typical system for dryland pastures in WA and should remain adequately 
supplied with $\mathrm{Zn}$ for $>15$ years after a typical initial application of $1 \mathrm{~kg} \mathrm{Zn} \mathrm{ha}{ }^{-1}$, or longer if pastures are topdressed with $\mathrm{P}$ fertiliser enriched with $\mathrm{Zn}$.

\section{Summary of the residual value of micronutrient fertiliser for} 5 pasture

Similar to $\mathrm{Zn}, \mathrm{Cu}$ has a long residual value and frequent additions of $\mathrm{Cu}$ are not required (Table 2). The residual value of Mo in south-west WA was estimated to be 5-10 years, whereas in subtropical and tropical regions, the residual effectiveness was

10 only 2-5 years (Table 2). By contrast, Fe applied to the soil surface for 1 year was $\sim 60 \%$ as effective as Fe sulfate applied immediately before pasture growth commenced, whereas $\mathrm{Fe}$ applied 5 years before was about one-third as effective as the recently applied $\mathrm{Fe}$ for herbage production (Brennan and 5 Highman 2001).

Most of the estimates of residual value of micronutrient fertilisers have been derived from studies with crops. For pasture species, differences are likely among species and cultivars for uptake of micronutrients such as $\mathrm{Zn}$ (Grewal and

20 Williams 1999) that would need to be accounted for when determining the residual value of fertiliser. For example, among 15 lucerne cultivars that differed in $\mathrm{Zn}$ efficiency, there was a 2-fold difference in $\mathrm{Zn}$ uptake by shoots under $\mathrm{Zn}$-deficient conditions, but with adequate $\mathrm{Zn}$ supply in the 5 soil, all cultivars absorbed similar amounts of $\mathrm{Zn}$ into shoots (Grewal and Williams 1999). Cultivar differences in residual value of micronutrient fertiliser have not been researched. Similarly, there are no data on residual value for the newer pasture species such as legumes serradella (Ornithopus sativus 30 Brot.), annual medics, tedera (Bituminaria bituminosa) and biserrula (Biserrula pelecinus (L.) C.H.Stirt.) and a range of grasses such as Italian ryegrass (Lolium multiflorum Lam.) now grown in pasture systems. The residual values of $\mathrm{B}, \mathrm{Se}$ and $\mathrm{Mn}$ are poorly defined for Australia pasture-animal systems. 35 Similarly, the residual value of micronutrients may have changed as a result of the effects of liming on acid soils.

\section{Micronutrient diagnosis and prognosis of deficiency}

Soil and plant tests are used for the initial diagnosis of micronutrient disorders, and to determine when a re40 application of micronutrient fertiliser is needed. However, total soil levels of $\mathrm{Cu}, \mathrm{Zn}, \mathrm{Mn}, \mathrm{B}$ or $\mathrm{Fe}$ in agricultural soils are poor predictors of micronutrient deficiency in pasture plants

Table 2. Residual values proposed for a range of micronutrients for pasture production and animal nutrition, based on the recommended application to originally deficient soil for set-stocking systems in southwest Australia or for tropical pastures

\begin{tabular}{lcl}
\hline Element & Residual value (years) & Source \\
\hline Copper & $15-20$ & Brennan 2006 \\
Zinc & $15-20$ & Brennan and Bolland 2006, 2007 \\
Molybdenum & $5-10$ & Brennan 2002 \\
& $2-5^{\text {A }}$ & Johansen et al. 1977 \\
Iron & $2-3$ & Brennan and Highman 2001 \\
Cobalt & $1-2$ & Adams et al. 1969 \\
\hline
\end{tabular}

${ }^{\mathrm{A}}$ For tropical pasture legumes, on a range of soil types. because plant availability depends on the form of the micronutrients in soils, which in turn is determined by soil $\mathrm{pH}$, organic matter content, adsorptive surfaces, and other physical, chemical, and biological conditions in the rhizosphere (Bell and Dell 2008).

In general, inaccurate soil and plant test results are more likely with micronutrients than with macronutrients because, by definition, they are present in very low concentrations so that the risk of results being affected by contamination is high. Analytical methods such as inductively coupled plasma-mass spectrometry have greater sensitivity, and therefore greater ability to determine low concentrations than the methods used when much of the Australian soil micronutrient research was completed. Errors may arise at various stages of the soil or plant testing process. Appropriate procedures for sampling the soil or pasture are essential to achieving accurate analytical results, and are particularly important with soil because of the marked spatial variability that occurs in paddocks. Herbage may be contaminated by soil before or during collection, or by dust during the drying and grinding operations, and such contamination will increase the apparent concentration of micronutrient elements, especially $\mathrm{Fe}, \mathrm{Co}$ and I, whose concentration is much greater in soil than in plant material.

Samples, particularly of plant material, can be subject to contamination from the packaging used during collection or storage; various types of plastic and paper contain appreciable amounts of some micronutrient elements, especially $\mathrm{Zn}$ and B (Bell and Dell 2008). In addition, soil, plant and animal tissue samples can all be contaminated during drying and grinding through abrasion of the grinding mechanism. Steel components may contaminate the sample with $\mathrm{Fe}$, brass components may add $\mathrm{Cu}$ and $\mathrm{Zn}$, and rubber fittings may add Zn (Bell and Dell 2008).

\section{Soil tests}

Micronutrient availability in soils can be assessed by using chemical and biological tests. Various chemical extractants including mineral acids (e.g. $1 \mathrm{~N} \mathrm{HCl}$ ), salt solutions (e.g. 0.01 $\mathrm{M} \mathrm{CaCl}_{2}$ ), buffer solutions (e.g. $1 \mathrm{M} \mathrm{NH} \mathrm{NH}_{4} \mathrm{OAc}$ ) and chelating agents (e.g. DTPA) have been used to measure micronutrient availability in soils (Sutton et al. 1984; Payne et al. 1988; Sims and Johnson 1991; van der Watt et al. 1994). For micronutrient metals, chelating agents such as EDTA and DTPA are usually more reliable (Sims and Johnson 1991) because they are more effective in removing potentially plant-available soil fractions. One of the most well-calibrated soil tests for micronutrients in pastures in southern Australia is the DTPA $\mathrm{Zn}$ soil test, developed for prognosis of potential $\mathrm{Zn}$ deficiency in subterranean clover (Brennan and Gartrell 1990). Development of similar calibrations for $\mathrm{Zn}$ on other pasture species would require many new field experiments on a range of soil types. Considering that $\mathrm{Zn}$ deficiency rarely exists now owing to the widespread use of fertilisers that contain $\mathrm{Zn}$, the conditions are not available to acquire such new experimental data readily. The more feasible approach will be to determine the response of the new species relative to that of subterranean clover on a limited selection of soil types. A similar approach was suggested by Conyers et al. (2013) to address the paucity of soil test data for pulses and oilseeds relative to wheat. 
Reuter et al. (1983) suggested that plant species differ in characteristics of $\mathrm{Cu}$ uptake and translocation within the plant. Therefore, it is likely that separate calibrations for soil $\mathrm{Cu}$ will be required for different plant species, as has been found for soil

5 testing for phosphorus (Bell et al. 2013a, 2013b). We consider it highly unlikely that soil-test $\mathrm{Cu}$ calibrations will now be developed for a range of pastures on different soils in Australia. This would require many field experiments over many years, as well as a range of soil types that are $\mathrm{Cu}$ -

10 deficient. Such conditions are less common now owing to widespread use of fertiliser $\mathrm{Cu}$ on soils that were originally deficient across Australia. As discussed above for $\mathrm{Zn}$, there would be merit in determining the response of new pasture species to $\mathrm{Cu}$ relative to the response of subterranean clover.

15 It would then be feasible to adapt the clover $\mathrm{Cu}$ decision tools to the alternative pasture species.

Critical values for predicting micronutrient limitations in pastures are reported in Peverill et al. (1999). Most of the soil tests are based on sampling the $0-10 \mathrm{~cm}$ layer during the dry

20 season and using standardised laboratory methods (Rayment and Lyons 2011).

Although soil tests are not as accurate as plant tests for predicting micronutrient deficiencies, they can be useful for a general assessment of the risk of deficiency, and to identify

25 changes in availability due to soil-management practices such as lime application and no-till cropping and as a consequence of increasing acidity.

An alternative approach was developed by Wong et al. (2005) for $\mathrm{B}$, for which no calibrated soil tests had been developed. This

30 involved developing a risk-prediction map for B deficiency based on soil $\mathrm{pH}$, soil texture, geology, and limited cases of $\mathrm{B}$ response in crops to B fertiliser in pot experiments. This approach could be applied across pasture-growing areas in Australia to develop deficiency risk maps that reflect current farming systems as well

35 as the inherent risk of deficiencies as described by Hayes et al. (2019).

\section{Plant tests}

Plant tests are inherently more reliable than soil tests for predicting micronutrient deficiencies because the

40 concentration in the plant relates directly to plant requirements and represents the integrated effect of various factors that determine uptake by the plant, (Smith and Loneragan 1997). Plant tests are used for diagnosis of observed or suspected disorders (deficiency or toxicity), for 45 the prognosis or prediction of a disorder that may emerge later in the growing season, or for monitoring long-term trends in nutrient status (Smith and Loneragan 1997). The most accurate plant tests are those based on defined young leaves of pasture species (Smith and Loneragan 1997). Such

50 leaves tend to reflect current nutrient supply to the plant from soils and hence reflect the current availability for pasture growth.

Whole shoot samples are used by some commercial testing services (e.g. NUlogic; CSBP, Kwinana, WA). Whole shoots are easier to sample but may reflect earlier growth conditions and soil nutrient supply rather than current conditions. In the case of the phloem-immobile or variably mobile micronutrients $(\mathrm{B}, \mathrm{Cu}, \mathrm{Fe}$, $\mathrm{Mn}, \mathrm{Zn}$ ), high concentrations that accumulated in old leaves during early growth may give a false diagnosis of adequate supply (Smith and Loneragan 1997); in the same plants, under current soil supply, young leaves may contain deficient concentrations.

Whether young leaves or whole shoots are sampled, diagnosis depends on calibrated critical concentration or critical ranges for that nutrient defined for a specified time of sampling. Reuter and Robinson (1997) provide the most comprehensive listing for pasture species in Australia of critical concentrations for the diagnosis and prognosis of micronutrient deficiencies. A selection of critical concentrations is provided in Table 3. However, there is a paucity of calibrated critical-range data for micronutrient deficiencies in new pastures species.

\section{Fertiliser decision-making practices for micronutrients}

For micronutrients such as $\mathrm{Cu}, \mathrm{Zn}$ and Mo that generally have a long residual effectiveness in soils, paddock-by-paddock records of the last time of micronutrient fertiliser application probably provide the most useful information for micronutrient-fertiliser decision making. Simple models such as that of Brennan (2005), as reported in Bell and Dell (2008), based on estimated availability of fertiliser, annual removal and the input from fertiliser can be useful in estimating the frequency of reapplication (Table 4). Based on this model, in cases where Zn-enriched fertilisers are applied regularly, Zn supply to pastures should be indefinitely adequate as long as there is no major change in rate of removal or an increase in $\mathrm{Zn}$ reaction with the soil. Lime application is a soil-management practice that may decrease availability and hence trigger a need to re-assess the residual value of the $\mathrm{Zn}$ fertiliser (Brennan et al. 2005).

Another approach would be to conduct soil tests every 5-7 years to monitor the micronutrient status in soils that have previously had additions of micronutrient fertiliser and are receiving small supplementary additions on a regular basis in macronutrient fertiliser. Although soil testing is not as reliable for predicting crop responses to micronutrient fertilisers, repeated soil testing over time can be useful for establishing a time trend. This use of soil testing should detect declines over time in availability, or significant changes in availability due to lime or other soil-management practices.

Plant tests early in the season can be used to determine whether remedial applications by foliar application are needed during the season.

Table 3. A selection of critical concentrations $\left(\mathrm{mg} \mathrm{kg}^{-1}\right)$ of micronutrients for maximum pasture production, in youngest open leaves and whole shoots of subterranean clover before flowering (Pinkerton et al. 1997)

\begin{tabular}{lcc}
\hline & Youngest open leaves & Whole shoots \\
\hline Copper & $4.3-5.5$ & $<3.5-4.5$ \\
Zinc & $15-25$ & $10-15$ \\
Molybdenum & $0.1-0.2$ & $0.1-0.2$ \\
Boron & $20-24$ & - \\
Iron & $50-75$ & - \\
Manganese & $15-20$ & - \\
Cobalt & $<0.04$ & $<0.04-0.10$ \\
\hline
\end{tabular}


Table 4. Budget for zinc (Zn) inputs and outputs for a typical pastureley rotation in south-west Australia on a low-Zn sandy loam soil with an initial application of $0.75 \mathrm{~kg} \mathrm{Zn} \mathrm{ha}^{-1}$, as recommended Source: Brennan (2005)

\begin{tabular}{lccccc}
\hline & $\begin{array}{c}\text { Yield } \\
\left(\mathrm{t} \mathrm{ha}^{-1}\right)\end{array}$ & $\begin{array}{c}\mathrm{Zn} \text { in produce } \\
\left(\mathrm{mg} \mathrm{kg}^{-1}\right)\end{array}$ & $\begin{array}{c}\mathrm{Zn} \\
\text { removed }\end{array}$ & $\begin{array}{c}\mathrm{Zn} \text { added } \\
\left(\mathrm{g} \mathrm{ha}^{-1}\right)\end{array}$ & $\begin{array}{c}\mathrm{Zn} \\
\text { balance }\end{array}$ \\
\hline $\begin{array}{l}\text { Pasture and clean } \\
\quad 0.04\end{array}$ & 110 & 3.5 & $90^{\mathrm{A}}$ & 86.5 \\
$\quad$ wool (P) & & & & & \\
Wheat (W) & 1.5 & 22 & 33 & 0 & -33 \\
Lupin (L) & 1.1 & 30 & 33 & 0 & -33 \\
Canola (C) & 1.1 & 30 & 33 & 0 & -33 \\
Sum & & & & & -12.5 \\
No. of cycles of & & & $42^{\mathrm{B}}$ & & \\
$\quad$ P-W-L-C & & & & & \\
\hline
\end{tabular}

$\overline{{ }^{\mathrm{A}} \text { Assumes } \mathrm{Zn} \text {-enriched superphosphate used to supply phosphorus and } \mathrm{Zn}}$ during the pasture phase of the rotation.

${ }^{\mathrm{B}}$ The number of cycles is based on the amount of Zinc available for uptake minus the amounts removed per cycle. Zinc available for uptake is the proportion of the applied fertiliser $\mathrm{Zn}$ that remains in the plant-available pool, and depends on the $\mathrm{Zn}$-sorption capacity of the soil, which in the calculation was $70 \%$, based on Brennan (2005).

Micronutrient additions in dairy systems are primarily focused on animal health rather than pasture production; therefore, these micronutrient deficiencies are usually corrected by using animalbased interventions such as licks, injections or boluses. Decisions 5 about micronutrient interventions for animal health are usually informed by past or present deficiency symptoms in the animals on the farm or at a nearby farm, or, more rarely, by soil or forage test results (PJM Raedts, pers. comm.).

The majority of Australian dairy farmers are using $\mathrm{N}$-fertiliser

10 application to drive pasture growth and are wary of having a large legume component because of the risk to livestock of bloat. Therefore, they tend to have a small legume component in their sward. Hence, Co and Se, which are required by rhizobia but not for grass growth, are not often applied directly to pastures in dairy 15 systems. Furthermore, even the models and courses that researchers, advisors and consultants use to make fertiliser decisions or give fertiliser guidance, such as DairyMod (Johnson 2016), SGS Pasture Model (Johnson 2016), Dairy N Fertiliser Advisor (Stott et al. 2015) and Fert\$mart (Dairy Soils

20 and Fertiliser Manual Team 2013), have little or no inclusion of micronutrient management and fertilisation. Inclusion of micronutrients in these models and courses could be useful to improve animal health and legume $\mathrm{N}$ fixation for organic and low-input systems.

\section{Conclusions}

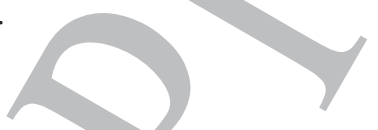

For management of micronutrients in pastures, growers face a dilemma. On the one hand, for old clover-based pastures systems in WA and SA, there is rich literature on management of micronutrients, especially $\mathrm{Co}, \mathrm{Cu}$, Mo and $\mathrm{Zn}$ (less so $\mathrm{Mn}$ ).

30 However, it is not clear how much of this knowledge can still be applied in those areas because of changes in farming systems and practices, or whether it is reasonable to extrapolate to other parts of Australia with different soils, climates and pasture species. On the other hand, there is limited contemporary research updated assessment of micronutrient status in representative pasture systems in Australia is warranted, to define the knowledge gaps that are hampering pasture productivity or animal productivity and health.

\section{Acknowledgements}

The authors declare no conflicts of interest. This research did not receive any specific funding.

\section{References}

Adams SN, Honeysett JL, Tiller KG, Norrish K (1969) Factors controlling the increase of cobalt in plants following the addition of a cobalt fertilizer. Australian Journal of Soil Research 7, 29-42. doi:10.1071/SR9690029

Becana M, Dalton DA, Moran JF, Iturbe-Ormaetxe I, Matamoros MA, Rubio MC (2000) Reactive oxygen species and antioxidants in legume nodules. Physiologia Plantarum 109, 372-381. doi:10.1034/j.13993054.2000.100402.x

Bell RW (1999) Boron. In 'Soil analysis: an interpretation manual'. (Eds K Peverill, L Sparrow, DJ Reuter) pp. 309-317. (CSIRO Publishing: Melbourne)

Bell RW, Dell B (2008) 'Micronutrients in sustainable food, feed, fibre and bioenergy production.' (International Fertiliser Association: Paris)

Bell MJ, Moody PW, Anderson GC, Strong W (2013a) Soil phosphorus crop response calibration relationships and criteria for oilseeds, grain legumes and summer cereal crops grown in Australia. Crop \& Pasture Science 64, 499-513.

Bell RW, Reuter DJ, Scott B, Sparrow L, Strong W, Chen W (2013b) Soil phosphorus - crop response calibration relationships and criteria for winter cereal crops grown in Australia. Crop \& Pasture Science 64, 480-498. doi:10.1071/CP13016

Blevins DG, Lukaszewski KM (1998) Boron in plant structure and function. Annual Review of Plant Physiology and Plant Molecular Biology 49, 481-500. doi:10.1146/annurev.arplant.49.1.481

Bolaños L, Brewin NJ, Bonilla I (1996) Effects of boron on Rhizobium-legume cell-surface interactions and nodule development. Plant Physiology 110, 1249-1256. doi:10.1104/pp.110.4.1249

Brear E, Day D, Smith P (2013) Iron: an essential element for the legumerhizobium symbiosis. Frontiers in Plant Science 4, 359. doi:10.3389/ fpls.2013.00359

Brennan RF (1998) Zinc. In 'SoilGuide: a handbook for understanding and managing agricultural soils'. Bulletin 4343. (Ed. G Moore) pp. 189-192. (Agriculture Western Australia: South Perth, W. Aust.)

Brennan RF (2000) Zinc. In 'The wheat book: principle and practices'. Bulletin 4443. (Eds WK Anderson, G Garlinge) pp. 98-99. (Agriculture Western Australia: South Perth, W. Aust.)

Brennan RF (2002) Residual value of molybdenum trioxide for clover production on an acidic sandy podzol. Australian Journal of Experimental Agriculture 42, 565-570. doi:10.1071/EA01066

Brennan RF (2005) Zinc application and its availability to plants. PhD Thesis, Murdoch University, Murdoch, W. Aust.

Brennan RF (2006) Long-term residual value of copper fertiliser for production of wheat grain. Australian Journal of Experimental Agriculture 46, 77-83. doi:10.1071/EA04271

Brennan RF, Bolland MDA (2006) Residual values of soil-applied zinc fertiliser for early vegetative growth of six crop species. Australian Journal of Experimental Agriculture 46, 1341-1347. doi:10.1071/ EA05154

Brennan RF, Bolland MDA (2007) Estimating the long-term residual value of zinc oxide for growing wheat in a sandy duplex soil. Australian Journal of Agricultural Research 58, 57-65. doi:10.1071/AR06169

Brennan RF, Gartrell JW (1990) Reactions of zinc with soil affecting its availability to clover. I. The relationship between critical concentrations of extractable zinc and properties of Australian soils responsive to applied 
zinc. Australian Journal of Soil Research 28, 293-302. doi:10.1071/ SR9900293

Brennan RF, Highman DD (2001) Residual value of ferrous sulfate for clover production on humic sandy podsols. Australian Journal of Experimental Agriculture 41, 633-639. doi:10.1071/EA00196

Brennan RF, McGrath JF (1988) The vertical movement of zinc on sandy soils in southern Western Australia. Australian Journal of Soil Research 26, 211-216. doi:10.1071/SR9880211

Brennan RF, Bolland MDA, Bell RW (2005) Increased risk of zinc deficiency in wheat on soils limed to correct soil acidity. Australian Journal of Soil Research 43, 647-657. doi:10.1071/SR04162

Broadley MR, White PJ, Hammond JP, Zelko I, Lux A (2007) Zinc in plants. New Phytologist 173, 677-702. doi:10.1111/j.1469-8137.2007.01996.x

Brown PH, Cakmak I, Zhang Q (1993) Form and function of zinc plants. In 'Zinc in soils and plants'. (Ed. AD Robson) pp. 93-106. (Springer: Dordrecht, The Netherlands)

Brown PH, Bellaloui N, Wimmer MA, Bassil ES, Ruiz J, Hu H, Pfeffer H, Dannel F, Romheld V (2002) Boron in plant biology. Plant Biology 4, 205-223. doi:10.1055/s-2002-25740

20 Campbell LC, Nable RS (1988) Physiological function of manganese in plants. In 'Manganese in soils and plants'. (Eds RD Graham, RJ Hannam, NC Uren) pp. 87-95. (Kluwer Academic Publishers: Dordrecht, The Netherlands)

Conyers MK, Bell M, Wilhelm N, Norton R, Bell R, Walker C (2013) Making Better Fertiliser Decisions for Cropping Systems in Australia (BFDC): knowledge gaps and lessons learnt. Crop and Pasture Science 64, 539-547. doi:10.1071/CP13068

Crush JR, Lee JM, Cosgrove GP, Rossi L, Chapman DF, Stevens DR (2018) Foliar micronutrient concentrations of eight perennial ryegrass (Lolium perenne L.) cultivars grown in four regions in New Zealand. New Zealand Journal of Agricultural Research 61, 301-311. doi:10.1080/00288233.2018.1426020

Dairy Australia (2018) Our regions. Dairy Australia, Melbourne. Available at: http://www.legendairy.com.au/dairy-farming/our-industry/our-regions (accessed 20 January 2019)

Dairy Soils and Fertiliser Manual Team (2013) 'Dairy soils and fertiliser manual: Australian nutrient management guidelines.' (Dairy Australia: Melbourne)

de Caritat P, Cooper M, Wilford J (2011) The pH of Australian soils: field results from a national survey. Soil Research 49, 173-182. doi:10.1071/ SR10121

Doole G, Weetman E (2009) Tactical management of pasture fallows in Western Australian cropping systems. Agricultural Systems 102, 24-32. doi:10.1016/j.agsy.2009.06.002

45 Drennan CL, Huang S, Drummond JT, Matthews RG, Lidwig ML (1994) How a protein binds B12: A 3.0 A X-ray structure of B12-binding domains of methionine synthase. Science 266, 1669-1674. doi:10.1126/ science. 7992050

Dunshea FR, Walker GP, Williams R, Doyle PT (2019) Mineral and citrate concentrations in milk are affected by seasons, stage of lactation and management practices. Agriculture 9, 25. doi:10.3390/ agriculture9020025

Edmeades DC, Smart CE, Wheeler DM (1983) Effects of lime on the chemical composition of ryegrass and white clover grown on a yellow-brown loam. New Zealand Journal of Agricultural Research 26, 473-481. doi:10.1080/00288233.1983.10427024

Ekanayake LJ, Thavarajah D, McGee R, Thavarajah P (2017) Will selenium fertilization improve biological fixation in lentils? Journal of Plant Nutrition 40, 2392-2401. doi:10.1080/01904167.2017.1346670

60 Fitzpatrick EN (2011) 'In response to need: a history of the Western Australian Department of Agriculture 1894-2008.' (Department of Agriculture and Food, Western Australia: South Perth, W. Aust.)

Forbes JC, Gelman AL (1981) Copper and other minerals in herbage species and varieties on copper-deficient soils. Grass and Forage Science 36, 25-30. doi:10.1111/j.1365-2494.1981.tb01535.x
Gartrell JW (1981) Distribution and correction of copper deficiency in crops and pastures. In 'Copper in soils and plants'. (Eds JF Loneragan, AD Robson, RD Graham) pp. 313-350. (Academic Press: Sydney)

Gazey C, Davies S, Master R (2014) 'Soil acidity: a guide for WA farmers and consultants.' Bulletin 4858. (Department of Agriculture and Food, Western Australia: South Perth, W. Aust.)

Gerendás J, Polacco JC, Freyermuth SK, Sattelmacher B (1999) Significance of nickel for plant growth and metabolism. Journal of Plant Nutrition and Soil Science 162, 241-256. doi:10.1002/(SICI)1522-2624(199906) 162:3<241::AID-JPLN241>3.0.CO;2-Q

González-Guerrero M, Matthiadis A, Sáez Á, Long TA (2014) Fixating on metals: new insights into the role of metals in nodulation and symbiotic nitrogen fixation. Frontiers in Plant Science 5, 45. doi:10.3389/ fpls.2014.00045

Grace ND (1983) Amounts and distribution of mineral elements associated with fleece-free body weight gains in the grazing sheep. New Zealand Journal of Agricultural Research 26, 59-70. doi:10.1080/00288233. 1983.10420952

Grewal HS, Williams R (1999) Alfalfa genotypes differ in their ability to tolerate zinc deficiency. Plant and Soil 214, 39-48. doi:10.1023/ A:1004610110327

GuptaUC (1971) Boron and molybdenum nutrition of wheat, barley, and oats grown in Prince Edward Island soils. Canadian Journal of Soil Science 51, 415-422. doi:10.4141/cjss71-056

Hänsch R, Mendel RR (2009) Physiological functions of mineral micronutrients $(\mathrm{Cu}, \mathrm{Zn}, \mathrm{Mn}, \mathrm{Fe}, \mathrm{Ni}, \mathrm{Mo}, \mathrm{B}, \mathrm{Cl})$. Current Opinion in Plant Biology 12, 259-266. doi:10.1016/j.pbi.2009.05.006

Hayes RC, Ara I, Badgery WB, Culvenor RA, Haling RE, Harris CA, Li GD, Norton MR, Orgill SE, Penrose B, Smith RW (2019) Prospects for improving perennial legume persistence in mixed grazed pastures of south-eastern Australia, with particular reference to white clover. Crop and Pasture Science 70, xxx. doi:10.1071/CP19063

Hill GM, Ku PK, Miller ER, Ulley DE, Losty TA, O’Dell BL (1983a) A copper deficiency in neonatal pigs induced by a high zinc maternal diet. The Journal of Nutrition 113, 867-872. doi:10.1093/jn/113.4.867

Hill GM, Miller ER, Ku PK (1983b) Effect of dietary zinc levels on mineral concentration in milk. Journal of Animal Science 57, 123-129. doi: $10.2527 /$ jas $1983.571123 x$

Hill GM, Miller ER, Whetter PA, Ulley DE (1983c) Concentration of minerals in tissues of pigs from dams of different levels of dietary zinc. Journal of Animal Science 57, 130-138. doi:10.2527/ jas1983.571130x

Hyder MW, Thompson AN, Doyle PT, Tanaka K (2002) The response of broad- and fine-wool Merino wethers to differential grazing of annual pastures during spring. Australian Journal of Experimental Agriculture 42, 117-128. doi:10.1071/EA00008

Johansen CJ, Kerridge PC, Luck PE, Cook BG, Lowe KF, Ostrowski H (1977) The residual effect of molybdenum fertilizer on growth of tropical pasture legumes in a sub-tropical environment. Australian Journal of Experimental Agriculture and Animal Husbandry 17, 961-968. doi:10.1071/EA9770961

John MK, Eaton GW, Case VW, Chuah HH (1972) Liming of alfalfa (Medicago sativa L.) II. Effect on mineral composition. Plant and Soil 37, 363-374. doi:10.1007/BF02139979

Johnson IR (2016) 'DairyMod and the SGS Pasture Model: a mathematical description of the biophysical model structure'. (IMJ Consultants: Dorrigo, NSW)

Jones RJ, Loch DS, LeFeuvre RP (1995) Differences in mineral concentration among diploid and tetraploid cultivars of Rhodes grass (Chloris gayana). Australian Journal of Experimental Agriculture 35, 1123-1129. doi:10.1071/EA9951123

Judson GJ, McFarlane JD (1998) Mineral disorders in grazing livestock and the usefulness of soil and plant analysis in the assessment of these disorders. Australian Journal of Experimental Agriculture 38, 707-723. doi:10.1071/EA97145 
Lee HJ (1956) The influence of copper deficiency on the fleeces of British breeds of sheep. The Journal of Agricultural Science 47, 218-224. doi: $10.1017 /$ S0021859600040144

León-Mediavilla J, Senovilla M, Montiel J, Gil-Díez P, Saez Á, Kryvoruchko 5 IS, Reguera M, Udvardi MK, Imperial J, González-Guerrero M (2018) MtMTP2-facilitated zinc transport into intracellular compartments is essential for nodule development in Medicago truncatula. Frontiers in Plant Science 9, 990. doi:10.3389/fpls.2018.00990

Lindström BE, Frankow-Lindberg BE, Dahlin AS, Wivstad M, Watson CA (2013) Micronutrient concentrations in common and novel forage species and varieties grown on two contrasting soils. Grass and Forage Science 68, 427-436. doi:10.1111/gfs. 12006

Marschner P (2011) 'Marschner's mineral nutrition of higher plants.' 3rd edn (Academic Press: New York)

15 Masters DG, Moir RJ (1980) Provision of zinc to sheep by means of an intraruminal pellet. Australian Journal of Experimental Agriculture and Animal Husbandry 20, 547-551. doi:10.1071/EA9800547

Masters DG, Somers M (1980) Zinc status of grazing sheep: seasonal changes in zinc concentration in plasma, wool and pasture. Australian Journal of Experimental Agriculture and Animal Husbandry 20, 20-24. doi:10.1071/EA9800020

Millaleo R, Reyes-Díaz M, Ivanov AG, Mora ML, Alberdi M (2010) Manganese as essential and toxic element for plants: transport, accumulation and resistance mechanisms. Journal of Soil Science and Plant Nutrition 10, 470-481. doi:10.4067/S0718-95162010000200008

Miller WJ, Neathery MW, Gentry RP, Blackman DM, Stake PE (1974) Adaptations in zinc metabolism by lactating cows fed a low zinc practical-type diet. In 'Trace element metabolism in animals-TEMA 2'. (Ed. Hoekstra) pp. 550-552. (Uni. Park Press: Baltimore, USA)

30 Mills CF, Dalgarno AC, Williams RB, Quarterman J (1967) Zinc deficiency and the zinc requirements of calves and lambs. British Journal of Nutrition 21, 751-768. doi:10.1079/BJN19670076

Minson DJ (1990) 'Forage in ruminant nutrition.' (Academic Press: Sydney)

Mitchell RL (1963) Soil aspects of trace element problems in plants and animals. Journal of the Royal Agricultural Society 124, 75-86.

MLA (2018a) Cattle numbers - as at June 2017. Natural Resource Management Region. Meat \& Livestock Australia, Sydney. Available at: https://www.mla.com.au/globalassets/mla-corporate/ prices-markets/documents/trends-analysis/fast-facts-maps/sheepnumbers-map-2018-as-at-june-2017-data.pdf (accessed 20 January 2019)

MLA (2018b) Sheep numbers - as at June 2017. Natural Resource Management Region. Meat \& Livestock Australia, Sydney. Available at: https://www.mla.com.au/globalassets/mla-corporate/ prices-markets/documents/trends-analysis/fast-facts-maps/sheepnumbers-map-2018-as-at-june-2017-data.pdf (accessed 20 January 2019)

Moore GA, Sanford P, Wiley T (2006) 'Perennial pasture for Western Australia.' Bulletin 4690. (Department of Agriculture and Food Western Australia: South Perth, W. Aust.)

Naidu R, Kookana RS, Oliver DP, Rogers S, McLaughlin MJ (1996) 'Contaminants and the soil environment in the Australasia-Pacific region.' (Kluwer Academic Publishers: London)

O'Dell BL (Ed.) (1979) Copper and zinc in poultry nutrition. In 'National Feed Ingredients Association review on copper and zinc in animal nutrition'. pp. 1-62. (National Feed Ingredients Association: Des Moines, IA, USA)

O'Hara GW (2001) Nutritional constraints on root nodule bacteria affecting symbiotic nitrogen fixation: a review. Australian Journal of Experimental Agriculture 41, 417-433. doi:10.1071/EA00087

Payne GG, Martens DC, Kornegay ET, Lindemann MD (1988) Availability and form of copper in three soils following eight annual applications of copper-enriched swine manure. Journal of Environmental Quality 17, 740-746. doi:10.2134/jeq1988.00472425001700040038x
Peverill KI, Sparrow LA, Reuter DJ (Eds) (1999) 'Soil analysis: an interpretation manual.' (CSIRO Publishing: Melbourne)

Pinkerton A, Smith FW, Lewis DC (1997) Pasture species. In 'Plant analysis: an interpretation manual'. (Eds DJ Reuter, JB Robinson) pp. 287-346. (CSIRO Publishing: Melbourne)

Preisig O, Zufferey R, Thöny-Meyer L, Appleby CA, Hennecke H (1996) A high-affinity cbb3-type cytochrome oxidase terminates the symbiosisspecific respiratory chain of Bradyrhizobium japonicum. Journal of Bacteriology 178, 1532-1538. doi:10.1128/jb.178.6.1532-1538.1996

Price NO, Moschler WW (1965) Effect of residual lime in soil on minor elements in plants. Journal of Agricultural and Food Chemistry 13, 163-165. doi:10.1021/jf60138a020

Price NO, Moschler WW (1970) Residual lime effects in soils on certain mineral elements in barley, fescue and oats. Journal of Agricultural and Food Chemistry 18, 5-8. doi:10.1021/jf60167a044

Rayment GE, Lyons DJ (2011) 'Soil chemical methods: Australasia.' Australian Soil and Land Survey Handbooks Series (CSIRO Publishing: Melbourne)

Redondo-Nieto M, Rivilla R, El-Hamdaoui A, Bonilla I, Bolaños L (2001) Boron deficiency affects early infection events in the pea-Rhizobium symbiotic interaction. Functional Plant Biology 28, 819-823. doi:10.1071/PP01020

Reuter DJ, Robinson JB (Eds) (1997) 'Plant analysis: an interpretation manual.' (CSIRO Publishing: Melbourne)

Reuter DJ, Loneragan JF, Robson AD, Tranthim-Fryer DJ (1983) Variation in the external and internal copper requirements of subterranean clover. Agronomy Journal 75, 45-49. doi:10.2134/ agronj1983.00021962007500010011x

Rochecouste J-F, Crabtree W (2014) Conservation agriculture in Australian dry-land cropping. In 'Conservation agriculture: global prospects and challenges'. (Eds RA Jat, KL Sahrawat, AH Kassam) pp. 108-126. (CABI: Wallingford, UK)

Rumball W, Butler GW, Jackman RH (1972) Variation in nitrogen and mineral composition in populations of prairie grass (Bromus unioloides H.B.K.). New Zealand Journal of Agricultural Research 15, 33-42. doi:10.1080/00288233.1972.10421274

Schwarz G, Mendel RR (2006) Molybdenum cofactor biosynthesis and molybdenum enzymes. Annual Review of Plant Biology 57, 623-647. doi:10.1146/annurev.arplant.57.032905.105437

Sillanpää M (1982) 'Micronutrients and the nutrient status of soils: a global study.' Soils Bulletin No. 48. (Food and Agriculture Organization of the United Nations: Rome)

Sims J, Johnson GV (1991) Micronutrient soil tests. In 'Micronutrients in agriculture'. 2nd edn. SSSA Book Series No. 4. (Eds JJ Mortvedt, FR Cox, LM Shuman, RM Welch). pp. 427-476. (Soil Science Society of America: Madison, WI, USA).

Smith RM, Gawthorne JM (1975) The biochemical basis of deficiencies of zinc, manganese, copper and cobalt in animals. In 'Trace elements in soil-plant-animal systems'. pp. 243-258. (Academic Press: Sydney)

Smith FW, Loneragan JF (1997) Interpretation of plant analysis: concepts and principles. In 'Plant analysis: an interpretation manual'. (Eds DJ Reuter, JB Robinson) pp. 1-33. (CSIRO Publishing: Melbourne)

Spears JW (1999) Re-evaluation of the metabolic essentiality of the minerals-review. Asian-Australasian Journal of Animal Sciences 12, 1002-1008. doi:10.5713/ajas.1999.1002

Stewart JWB, McConaghy S (1963) Some effects of reaction (pH) changes in a basaltic soil on the mineral composition of growing crops. Journal of the Science of Food and Agriculture 14, 613-621. doi:10.1002/jsfa. 2740140903

Stott K, Malcolm B, Gourley C (2015) The 'Dairy N Fertiliser Advisor' - a tool to predict optimal $\mathrm{N}$ application rates in grazed dairy pastures. Agricultural Research Division Technical Report. The State of Victoria Department of Economic Development, Jobs, Transport and Resources, Melbourne. 
Sutton AL, Nelson DW, Mayrose VB, Kelly DT (1984) Effect of copper levels in swine manure on corn and soil. Journal of Environmental Quality 13, 198-203. doi:10.2134/jeq1984.00472425001300 010009x

5 Thompson AN, Doyle PT, Grimm M (1994) Effects of stocking rate in spring on liveweight and wool production on sheep grazing annual pastures. Australian Journal of Agricultural Research 45, 367-389. doi:10.1071/ AR9940367

Thompson AN, Hyder MW, Doyle PT (1997) Effects of differential grazing of annual pastures in spring and age of sheep on pasture and sheep production. Australian Journal of Experimental Agriculture 45, 367-389. doi:10.1071/AR9940367

Underwood EJ (1977) 'Trace elements in human and animal nutrition.' 4th edn (Academic Press: New York)

15 Underwood EJ, Mertz W (1987) Introduction. In 'Trace elements in human and animal nutrition'. 5th edn (Ed. W Mertz) pp. 1-19. (Academic Press: London)

Underwood EJ, Somers M (1969) Studies of zinc nutrition in sheep. I. The relation of zinc to growth, testicular development, and spermatogenesis in young rams. Australian Journal of Agricultural Research 20, 889-897. doi:10.1071/AR9690889

Underwood EJ, Suttle NF (1999) 'The mineral nutrition of livestock'. (CABI Publishing: Wallingford, UK)

van der Watt HVH, Sumner ME, Cabrera ML (1994) Bioavailability of copper, manganese and zinc in poultry manure. Journal of Environmental Quality 23, 43-49. doi:10.2134/jeq1994.00472425002300010008x

Vance CP (2008) Carbon and nitrogen metabolism in legume nodules. In 'Nitrogen-fixing leguminous symbioses'. (Eds MJ Dilworth, EK James,
JI Sprent, WE Newton) pp. 293-320. (Springer: Dordrecht, The Netherlands)

Verloo M, Willaert G (1990) Direct and indirect effects of fertilization practices on heavy metals in plants and soils. In 'Fertilization and the environment'. (Eds R Merckz, H Vereecken, K Vlassak) pp. 79-87. (Leuven University Press: Leuven, Belgium)

Welch RM, Shuman L (1995) Micronutrient nutrition of plants. Critical Reviews in Plant Sciences 14, 49-82. doi:10.1080/07352689509701922

White PJ, Broadley MR (2001) Chloride in soils and its uptake and movement within the plant: a review. Annals of Botany 88,967-988. doi:10.1006/ anbo.2001.1540

White JG, Zasoski RJ (1999) Mapping soil micronutrients. Field Crops Research 60, 11-26. doi:10.1016/S0378-4290(98)00130-0

White CL, Robson AD, Fisher HM (1981) Variation in nitrogen, sulfur, selenium, cobalt, manganese, copper and zinc contents of grain from wheat and two lupin species grown in a range of Mediterranean environments. Australian Journal of Agricultural Research 32, 47-59. doi:10.1071/AR9810047

White CL, Staines VE, Staines MH (2007) A review of the nutritional value of lupins for dairy cows Australian Journal of Agricultural Research 58, 185-202. doi:10.1071/AR06109

Whitehead DC (2000) 'Nutrient elements in grassland: soil-plant-animal relationships.' (CABI Publishing: Wallingford, UK)

Wong MTF, Bell RW, Frost K (2005) Mapping boron deficiency risk in soils of south-west Australia using a weight of evidence model. Australian Journal of Soil Research 43, 811-818. doi:10.1071/SR05022

Yruela I (2009) Copper in plants: acquisition, transport and interactions. Functional Plant Biology 36, 409-430. doi:10.1071/FP08288

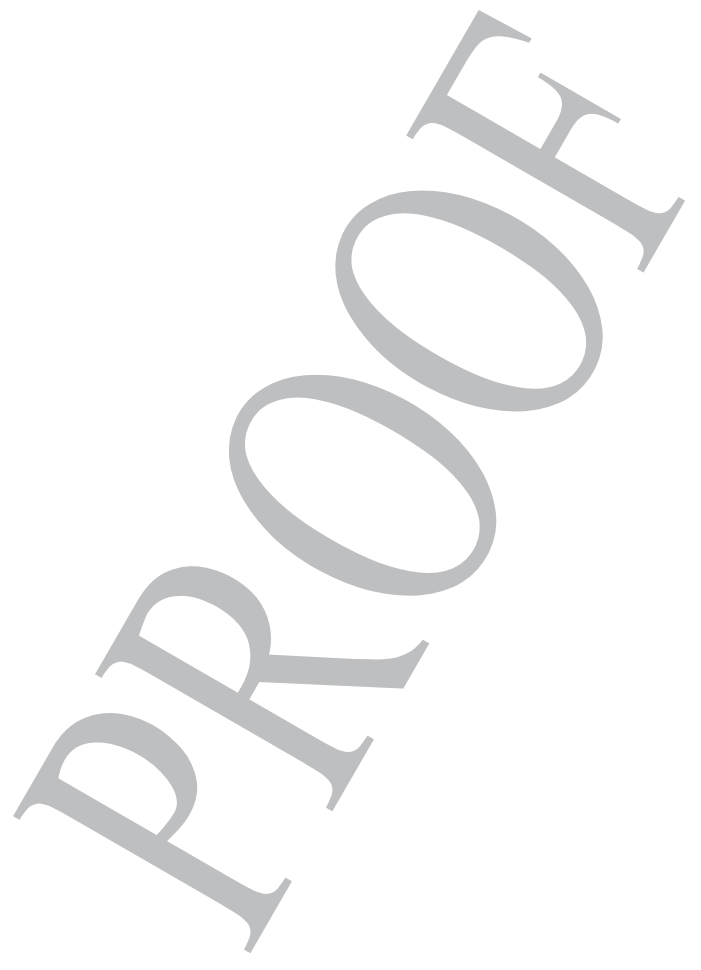

